\title{
The involvement of noradrenaline in rapid eye movement sleep mentation
}

\section{Claude Gottesmann*}

Département de Biologie, Université de Nice-Sophia Antipolis, Nice, France

Edited by:

Birendra N. Mallick, Jawaharlal Nehru University, India

\section{Reviewed by:}

Timo Partonen, University of Helsinki, Finland

Mitsuyuki Nakao, Tohoku University, Japan

\section{*Correspondence:}

Claude Gottesmann, Département de Biologie, Université de Nice-Sophia

Antipolis, 22, parc Lubonis, 06000

Nice, France.

e-mail: claude.gottesmann@unice.fr
Noradrenaline, one of the main brain monoamines, has powerful central influences on forebrain neurobiological processes which support the mental activities occurring during the sleep-waking cycle. Noradrenergic neurons are activated during waking, decrease their firing rate during slow wave sleep, and become silent during rapid eye movement (REM) sleep. Although a low level of noradrenaline is still maintained during REM sleep because of diffuse extrasynaptic release without rapid withdrawal, the decrease observed during REM sleep contributes to the mentation disturbances that occur during dreaming, which principally resemble symptoms of schizophrenia but seemingly also of attention deficit hyperactivity disorder.

Keywords: paradoxical sleep, catecholamines, dreaming, schizophrenia, ADHD, endophenotype
The nature of human mind activity varies greatly during the sleepwaking cycle. During waking, mental activity is reflective, logically organized, and involves learning processes that lead to memories. During slow wave sleep (SWS), mentation most often comprises "thought-like" content that is seldom visual and that has "a higher degree of correspondence with reality" ( $p$ 23; Foulkes, 1962; for ref. see Gottesmann, 2001). This mental content seems to correspond to the secondary process of Freud (1911), which follows the reality principle. As previously underlined by Rechtschaffen et al. (1963), during SWS these "secondary process characteristics. . are assigned to pre-conscious mentation" ( $p$ 546). Recent studies have shown that SWS mental activity reproduces or is the continuation of waking cognitive processes (Nielsen, 2003; Euston et al., 2007; Ji and Wilson, 2007). At the same time, it was shown early on that some dreams occur during SWS (Foulkes, 1962; Tracy and Tracy, 1974; Cavallero et al., 1992; Bosinelli, 1995; Cavallero, 2003), even though it has been emphasized that dreaming can only occur in the presence of certain neurobiological features of the rapid eye movement (REM) dreaming sleep stage (Takeuchi et al., 1999, 2001; Nielsen, 2003).

The mental activity of REM sleep has been "defined as an experience that involves vivid and complex multi-modal imagery, a progression of events and sense of reality" ( $p$ 180; Dement, 1965; for ref. see Gottesmann, 2005b); this is once again contrary to SWS mentation, which comprises "background thoughts that occur during the day" ( $p$ 180). Today, in fact, it is necessary to distinguish between the mental activity of REM sleep that occurs at sleep onset descending stage I (Sleep Onset REM Sleep: SOREM) and REM sleep occurring after ascending stage II, in more advanced night sleep stages. Even further, within the latter, some authors have distinguished between "active" dreams occurring during the REM bursts and "passive" ones occurring outside of these periods (Dement and Wolpert, 1958; Berger and Oswald, 1962); these studies, however, have not been followed up. It has been underlined by several authors, with the seeming exception of one recent study (Malcolm-Smith et al., 2007), that REM sleep dreaming is most often characterized by threatening content (Manacéine, 1897; Revonsuo, 2003). This is less often the case in SOREM, during which dreams are roughly equivalent in positive and negative content (Foulkes and Vogel, 1965; see Gottesmann, 2005b). Finally, with respect to the psychological quality of REM sleep mentation, it has been long noted by philosophers such as Kant and Schopenhauer, writers such as Alfred Maury, neurophysiopathologists such as Hughlings Jackson, and neuropsychiatrists such as Henri Ey, that numerous similarities exist between dreaming and madness (Gottesmann, 2010b). Today, the properties of dreams, with their hallucinatory perceptions, bizarre imagery, diminished self-reflective awareness, orientational instability, intensification of emotion, and instinctual behaviors (Hobson et al., 2000), are strongly reminiscent of the symptoms of schizophrenia (Gottesmann, 2005a, 2006; Gottesmann and Gottesman, 2007).

While various neurotransmitters [glutamate, gamma aminobutyric acid (GABA), and neuromodulators (acetylcholine, dopamine, serotonin, histamine...] also contribute to forebrain functioning, here I will attempt to provide a beginning of an explanation of how noradrenaline (NA) influences the mental activity occurring during REM sleep.

\section{CORTICAL NORADRENERGIC FUNCTION}

Noradrenergic neurons of the locus coeruleus (LC), the primary source of NA to the forebrain, fire maximally, although at a slow rate, during waking. Their discharges decrease during SWS and then become silent during REM sleep (Hobson et al., 1975; AstonJones and Bloom, 1981a; Rasmussen et al., 1986; Takahashi et al., 2010). As a consequence of this progression, both pontine (Shouse et al., 2000) and prefrontal cortex (Léna et al., 2005) release of NA is highest during waking and lowest during REM sleep. This 
neuromodulator plays important roles in the control of forebrain function. In certain rare cases of noradrenergic neuron stimulation in the LC, patients described "well being (and) improved clarity of. . . thinking" (p 179; Libet and Gleason, 1994). Moreover, numerous results have shown that NA depletion increases error responses to irrelevant stimuli and decreases responses in attentional tasks (Selden et al., 1990; Milstein et al., 2007); also, increased NA release is concomitant to cognitive improvement through the collection and processing of salient sensory information (Berridge and Waterhouse, 2003). The positive effect of NA on cognitive processes is further evidenced by the observation that attentional processes can be impaired by lesions of the dorsal NA bundle (Leconte and Hennevin, 1981; Tait et al., 2007) or by prefrontal neurotoxic inhibition of dopamine- $\beta$-hydroxylase (Milstein et al., 2007; McGaughy et al., 2008), the enzyme that catalyzes the conversion of dopamine to noradrenaline. As described by Arnsten and Pliszka (2011) "in humans, lower activity of dopamine- $\beta$ hydroxylase. . is associated with poor sustained attention (Greene et al., 2009), poor executive function (Kieling et al., 2008), and impulsiveness (Hess et al., 2009).”

There are two modalities of LC neuron activity. First, there is a basic tonic firing pattern, and second, a phasic firing pattern is superimposed onto the tonic firing. The tonic firing increases with vigilance, and its function is presumably to prevent unimportant sensory events from disturbing the perception of threshold and above-threshold stimuli (Berridge and Waterhouse, 2003; Johnson, 2003). In contrast, the phasic discharges are sensitive to novel sensory modifications of sub-threshold intensity, and increases in such discharges precede behavioral changes that can take place during tasks (Bouret and Sara, 2005). "Phasic NA activity serves to interrupt ongoing neural processes when a significant new event is experienced" (p 689; Johnson, 2003; see also Waterhouse et al., 1998). All LC neurons fire together, and only $10 \%$ of the neurons are sufficient to maintain normal cortical function (Berridge et al., 1993), because of compensatory NA neuron processes (Chiodo et al., 1983).

Noradrenaline was first shown to primarily inhibit cortical neurons (Krnjevic and Phillis, 1963; Frederickson et al., 1971; Nelson et al., 1973; Foote et al., 1975; Reader et al., 1979; Manunta and Edeline, 1999; Wang et al., 2010), specifically through $\alpha_{2}$ receptors. Noradrenaline has an important function in cortex efficiency, as it increases the fidelity of signal detection and transmission in neurons and synapses; it does this by increasing the signal-to-noise ratio of incoming information (Foote et al., 1975; Aston-Jones and Bloom, 1981b; Waterhouse et al., 1990; Warren and Dykes, 1996; Berlucchi, 1997), thereby reducing synaptic noise resulting from parasitic afferents relative to the informative stimulus (Berlucchi, 1997; Berridge and Waterhouse, 2003; for ref. see Gottesmann, 2008).

Noradrenaline acts through the $\alpha_{1}, \alpha_{2}$, and $\beta$ receptors. Prefrontal $\alpha_{1}$ receptor activation impairs cognitive processes, as shown through the administration of agonists to rats (Arnsten et al., 1999) and monkeys (Arnsten and Jentsch, 1997; Mao et al., 1999). In contrast, postsynaptic $\alpha_{2}$ receptor activation improves these processes (Steere and Arnsten, 1997; Mao et al., 1999), acting specifically in the prefrontal cortex (Ramos and Arnsten, 2007). This activation is restricted to the NA level (Arnsten and Li,
2005), in the maximal zone of an inverted U-curve (Arnsten and Dudley, 2005). It should be underlined that it is particularly the postsynaptic $\alpha_{2 a}$ receptors, whose activation threshold is much lower than that of the $\alpha_{1}$ receptors, which are responsible for this improvement in cognitive processes. Indeed, mice with mutations in the $\alpha_{2 \mathrm{a}}$ subtype show an unusual absence of improved working memory following administration of the $\alpha_{2 a}$ receptor-specific agonist guanfacine (Franowicz et al., 1998). At the postsynaptic level, the activation of these receptors reinforces the prefrontal connections between pyramidal cells by blocking potassium channels through the inhibition of cyclic adenosine monophosphate (cAMP), thereby "increasing the efficacy of network inputs, and facilitating prefrontal cortex function” (Arnsten and Pliszka, 2011). Beta receptors, which have the lowest affinity to NA and which activate pyramidal neurons (McCormick et al., 1991), have restricted influence on cognitive processes. Nevertheless, $\beta_{1}$ antagonists infused into the prefrontal cortex or administered systemically improve working memory in rats and monkeys, while $\beta_{1}-\beta_{2}$ receptor blocking compounds have no effect. Thus, prefrontal $\beta_{1}$ receptor activation appears to impair cognitive functions (Ramos et al., 2005).

Due to the silencing of the noradrenergic LC neurons during REM sleep, the level of NA in the prefrontal cortex drops from $20.9 \times 10^{-10} \mathrm{M}$ during waking to $9.98 \times 10^{-10} \mathrm{M}$ during this sleep period (Léna et al., 2005). A low level of NA is still maintained because it is diffusely released at the varicosity level (Fuxe et al., 1968; Descarries et al., 1977; Seguela et al., 1990), without rapid enzymatic destruction at the synapse by catecholamine- $O$-methyl transferase (COMT), or reuptake by transporters. However, this low level is insufficient to support normal cortical function. From a neurophysiological standpoint, NA is now well known to induce regular spiking activity in the cortex instead of burst firing (McCormick et al., 1993). However, it has long been established that the pyramidal neurons fire in bursts that are separated by silences of spiking during REM sleep, demonstrating a decrease in inhibitory influences controlling the frequency-limiting process (Evarts, 1964). Thus, the level of NA available during REM sleep is clearly insufficient to regularize pyramidal neuron firing. Since the affinity of NA is highest for the $\alpha_{2 a}$ receptors, these are likely the only ones activated during REM sleep to sustain normal prefrontal function. However, because of dorsolateral deactivation (Maquet et al., 1996; Braun et al., 1997; in spite of phasic activation during the eye movement bursts, particularly on the right side (Hong et al., 1995; Kubota et al., 2011 - but interestingly not related to LC phasic discharges; Takahashi et al., 2010, and K. Sakai, Personal Communication 2011) - and the lower levels of dopamine, serotonin, and acetylcholine (see Gottesmann, 2006, 2010a), NA is not sufficient to support normal prefrontal function by itself. In addition, there are reciprocal relations between the LC and the prefrontal cortex, with the latter promoting LC function (Jodo et al., 1998). It can be assumed that, in humans, the prefrontal dorsolateral deactivation that occurs during REM participates in the silencing of the LC, which in turn contributes to the impairment of cortical function. The strong decrease in cortical noradrenaline during REM sleep (Léna et al., 2005) probably also contributes to the abnormalities observed in synchronized gamma rhythms. Indeed, it has been shown that NA, but not serotonergic, reuptake inhibitors favor 
gamma rhythms in the septo-hippocampal system (Hajos et al., 2003) and that their intracortical and hippocampal synchronization is impaired during REM sleep (Perez-Garci et al., 2001; Cantero et al., 2004; Massimini et al., 2005; Montgomery et al., 2008), when cortical NA is at its lowest level. Thus, the cortex, and particularly the prefrontal cortex (which is the most phylogenetically recent structure to appear, responsible for the highest integrated processes), is impaired during REM sleep, as evidenced by its deactivation in the dorsolateral area and partly by the decrease in NA release. Simultaneously, the availabilities of dopamine (Léna et al., 2005), serotonin (Cespuglio et al., 1992), and acetylcholine (Marrosu et al., 1995) are also reduced, while the level of glutamate remains unchanged (Gottesmann, 2005a; Léna et al., 2005).

Another property of REM sleep is the inhibition of sensory afferents (Williams et al., 1962, 1964), which was first shown through an increased arousal threshold by peripheral stimulation (Dement and Kleitman, 1957; Dement, 1958; for ref. see Gottesmann, 2001). The notion of an involvement of cortical deactivation of primary sensory cortices (Braun et al., 1998) in the inhibition of afferents has been strongly challenged (Hong et al., 2009; Miyauchi et al., 2009). The thalamic transmission process is under the positive influence of postsynaptic $\alpha_{1}$ receptors, while $\alpha_{2}$ and $\beta$ receptors mediate inhibition; the facilitating influences follow an inverted U-curve (Devilbiss et al., 2006). During REM sleep, the decrease in noradrenaline levels possibly shifts the curve to the best functional level (Alsene et al., 2011), favoring postsynaptic activation (Sakakura and Iwama, 1965; Iwama et al., 1966; Dagnino et al., 1969; Ghelarducci et al., 1970; Gandolfo et al., 1980). In addition, the decreased NA level observed during REM sleep has both ascending and descending postsynaptic influences on thalamocortical neurons, since in addition to the above described ascending processes, corticothalamic glutamatergic influences (McCormick and Krosigk, 1992; Bonjean et al., 2011) are also disinhibited through NA silencing (Castro-Alamancos and Calcagnotto, 2001). In contrast, vestibular influences (Morrison and Pompeiano, 1966) and the (GABAergic) activation (or disinhibition) of the thalamic reticular nucleus (Hong et al., 2009) inhibit thalamic inputs. Indeed, it has been consistently shown that, particularly during the REM bursts occurring during REM sleep, there is a presynaptic inhibition of thalamic input (Sakakura and Iwama, 1965; Iwama et al., 1966; Dagnino et al., 1969; Ghelarducci et al., 1970; Gandolfo et al., 1980). This presynaptic inhibition can explain the increased sensory and arousal threshold that is present during REM sleep. Moreover, the absence of gamma rhythm resetting by peripheral stimulation during REM sleep (Llinas and Ribary, 1993) is presumably also related to sensory deafferentation. Finally, REM sleep is also characterized by an unexpected shortening of the cortical recovery cycle of responsiveness in both animals (Rossi et al., 1965; Allison, 1968) and humans, as shown by deficits in prepulse inhibition (Kisley et al., 2003). This failure of gate-control processes is certainly at least partly related to cortical NA disinhibition.

To conclude, although some results have supported the notion that the above described waking learning processes are replicated during REM sleep (Smith and Lapp, 1991; Hennevin et al., 1995, 2007; Smith, 1995; Peigneux et al., 2003) despite a strong NA deficit, these conclusions have been strongly disputed (Siegel, 2001; Vertes, 2004; Vertes and Siegel, 2005). Finally, and surprisingly, the rapid evanescence of dreams at arousal could be related to both the precocious recovery of waking NA processes (Gottesmann, 2008) and to the re-establishment associated with the late recovery of dorsolateral prefrontal cortex function (Balkin et al., 2002); both of these processes induce the withdrawal of insufficiently recorded memory traces.

Although the cortex and principally the "prefrontal circuits have the unique ability. . . to guide behavior, thought, and affect" (Ramos and Arnsten, 2007), other forebrain structures are also strongly involved in determining the mental activity associated with REM sleep.

\section{THE FIRST NEXT MAJOR STRUCTURE INVOLVED IN MENTATION IS THE NUCLEUS ACCUMBENS}

Dysfunction of this limbic structure is responsible for mental disturbances such as hallucinations and delusion. For decades, the main neuromodulator involved in its function was thought to be dopamine (MacKay et al., 1982). However, it is now known that the nucleus accumbens is subjected to strong glutamatergic influences originating from the prefrontal cortex (Brake et al., 2000; Jackson et al., 2001), hippocampus (Lipska et al., 1993), and amygdala (Floresco et al., 1998). This structure also has NA afferents mainly originating in the medulla oblongata $A_{1}$ and $A_{2}$ nuclei, and secondarily from the LC (Delfs et al., 1998). These influences are now considered to be important, since the NA concentration in the nucleus accumbens is as high as that of dopamine (Tong et al., 2006) and varies in parallel with the level of glutamate (Swanson and Schoepp, 2003; Léna et al., 2005).

Accumbal NA release is controlled by presynaptic $\alpha_{2}$ autoreceptors, the sensitivity of which varies with the NA concentration at the synapse (Aono et al., 2007; Verhelj and Cools, 2009a). Alpha2 receptor agonists promote dopamine release by inhibiting NA release (Pothos et al., 1991), and postsynaptic $\alpha_{2}$ receptors (heteroreceptors) inhibit dopamine release (Verhelj and Cools, 2009b). In some cases, $\beta$ receptor activation favors dopamine release (Misoguchi et al., 2008; Verhelj and Cools, 2009b). However, the activation thresholds of the different NA receptors (again, $\alpha_{2}<\alpha_{1}<\beta$ favor NA-mediated inhibition of dopamine release; as evidence of this, dopamine release is only increased after massive NA concentrations are attained by inhibition of reuptake (Misoguchi et al., 2008). Finally, noradrenaline also controls dopamine availability, as there is dopamine uptake at NA terminals (Carboni and Silvagni, 2004).

During REM sleep, the activation of the nucleus accumbens is evidenced by the presence of even more active neuron firing than occurs during waking (Callaway and Henriksen, 1992). The concentration of NA is minimal during this sleep stage (Léna et al., 2005). Although the $A_{1}$ and $A_{2}$ medulla oblongata nuclei have not been recorded during the sleep-waking cycle, they seem to be inhibited during REM sleep-like the LC; as confirmation of this, the firing of another low brainstem NA nucleus, $\mathrm{A}_{5}$, also becomes silent during REM sleep (Fenik et al., 2002). Because of the above described different influences that NA has on the regulation of dopamine, the near absence of NA is presumably, at least in part, responsible for the maximal dopamine release that takes place during REM sleep (Léna et al., 2005), and could explain the abnormal mental activity of dreaming, with its hallucinations and delusions 
characteristic of high accumbal levels of dopamine (MacKay et al., 1982).

In contrast to aspartate, glutamate release also decreases during REM sleep (Léna et al., 2005). This could be related to the prefrontal dorsolateral deactivation (Maquet et al., 1996; Braun et al., 1997), but could also partly result from hippocampal dysfunction. Indeed, although the same theta rhythm is present during REM sleep (Cadilhac et al., 1961; Michel et al., 1961) as during active waking (Jung and Kornmüller, 1938; Green and Arduini, 1954), hippocampal function should be different, particularly because of the noradrenergic (Segal, 1974; Segal and Bloom, 1976) and serotonergic (Segal, 1981, 1990) silence observed during REM sleep. For example, a nearly continuous hippocampal theta rhythm is observed not only in "cerveau isolé" transected cats (Tokizane, 1965; Olmstead and Villablanca, 1977) and rats (Gottesmann et al., 1980), but also in transections injuring the posterior hypothalamus (Glin et al., 1991). Thus, hippocampal electrophysiological field activity is not a faithful criteria of the functional state of this structure (Gottesmann, 2000) or of the level of glutamate released during REM sleep.

\section{THE SECOND STRUCTURE I WILL ADDRESS HERE IS THE AMYGDALA}

The amygdala is the main central structure involved in encoding emotional information and promoting avoidance learning storage (Ferry et al., 1999). Its afferents bring affectively charged information from the environment, and the amygdala triggers appropriate emotional responses. Several nuclei have a predominant function, and the output of the amygdala is primarily influenced by NA, as $54 \%$ of pyramidal neurons respond to NA whereas only nearly $3 \%$ respond to dopamine (Miyajima et al., 2010). First, the basolateral complex is considered one functional unit, since the basalis and lateral nuclei react similarly to NA, being inhibited in 64 and $74 \%$ of cases, respectively (Buffalari and Grace, 2007). The basolateral complex is reciprocally related to the $\mathrm{LC}$, with each structure activating the other. However, the amygdala also receives afferents from the medulla oblongata NA $A_{1}$ and $A_{2}$ nuclei. The centralis nucleus seems to be under the inhibitory control of the basolateral complex, and its efferents on the one hand are directed to the LC, also activating $\mathrm{A}_{2}$ and adrenergic $\mathrm{C}_{2}$ nuclei (Wallace et al., 1992; Bouret et al., 2003; the latter controlling LC functioning), and on the other hand promote hypothalamic vegetative influences supporting behavioral characteristics of stress (Cecchi et al., 2002; Buffalari and Grace, 2007). It is noteworthy that, in the same way, dorsal raphe nucleus afferents to the centralis nucleus inhibit the neurons (Jha et al., 2005), leading to a complementary disinhibition of glutamate output during REM sleep (Grace, 2000; Tran and Keele, 2011), and as a consequence of this, a reinforced affective load of mentation.

Both stimulation of the LC and stress increase the release of NA in the basolateral area (Buffalari and Grace, 2007), and NA deficits impair the consolidation of avoidance reactions and suppress c-Fos expression in the amygdala (Radwanska et al., 2010). Noradrenaline infusion into the basolateral area inhibits the majority of pyramidal neurons by activating GABAergic interneurons (Kaneko et al., 2008) via the activation of $\alpha_{1}$ receptors (Lazzaro et al., 2010). Emotional memory consolidation by NA has been confirmed in humans, since clonidine (an $\alpha_{2}$ receptor agonist) inhibits this process (Groch et al., 2011), while reboxetine (a reuptake inhibitor) promotes it (Gais et al., 2011). Moreover, the $\alpha_{2}$ receptor antagonist idazoxan infused into the basolateral amygdala enhances avoidance memory consolidation (Ferry and McGaugh, 2008). Finally, while NA and $\beta$-agonists favor avoidance memory consolidation while requiring $\alpha_{1}$ receptor activation in a first step (Ferry et al., 1999), magnetic resonance imaging (MRI) has shown that activation of the amygdala by emotional pictures, or verbal stimuli can be decreased by blockade of the $\beta$ receptor (Strange and Dolan, 2004; Stegeren van et al., 2005); consistent with this, $\beta$ antagonists are used as anxiolytics (Hurlemann et al., 2010).

The amygdala is activated during REM sleep, as was first shown by neuron recordings. There are units firing at a higher rate than during SWS (similar to the rate observed during waking; Reich et al., 1983; Zhang et al., 1986; Gulyani et al., 2002), as well as REM sleep-on specific neurons, which fire at high or low rates and which are disinhibited because of, at least in part, NA silence. Indeed, as both LC stimulation and footshocks inhibit neurons of the amygdala (Chen and Sara, 2007), the silence or near silence of LC neurons during REM sleep should also disinhibit the amygdala. Indeed, NA is strongly reduced in the amygdala during REM sleep [by from 61 (Park, 2002) to 85\% (Shouse et al., 2000) as compared to waking]. In addition, tomographic studies have also shown that the amygdala is activated during REM sleep (Maquet and Franck, 1997).

Since glutamate release is decreased in the nucleus accumbens during REM sleep, very probably as a result of prefrontal and hippocampal dysfunction, the remaining accumbal glutamate could mainly be a product of the (NA-mediated) disinhibition of the amygdala (Grace, 2000). The NA deficit present during REM sleep, like experimental deficits induced during waking, could impair amygdala (Strange and Dolan, 2004) and hippocampalbased (Kukolja et al., 2011) emotional encoding, and retrieval of mental processes (Murchison et al., 2011); this is the case even though an often excessive emotional activity is operative during REM sleep, explaining affectively loaded dreams. Moreover, glutamate release by the activation of the amygdala could participate in the increase in dopamine in the nucleus accumbens (Floresco et al., 1998), promoting hallucinations, and delusions during dreaming. As seen above, the nature of the emotional load during SOREM and REM sleep dreams appears to be different. Certainly partly due to NA influence, this distinction is probably related to differences in glutamate output in the amygdala. In this structure, NA seems to be more involved in the affective quality of mental activity than in the encoding of dreams, since SOREM dreams are not known to be better retrieved than REM sleep dreams.

A complementary neurobiological alternative to explain the rapid evanescence of dreams upon awakening (Gottesmann, 2006, 2008) could be the usually rapid reappearance of NA in the few seconds prior to behavioral arousal (Aston-Jones and Bloom, 1981a; Takahashi et al., 2010). This precocious restoration of some forebrain waking processes, with a highly probable re-establishment of intracortical (Perez-Garci et al., 2001; Corsi-Cabrera et al., 2003), intra-hippocampal (Montgomery et al., 2008), and hippocampocortical (Cantero et al., 2004) relations, could erase previous fragile memory traces (Gottesmann, 2008). This possible NA-mediated 
basis for forgetting upon exit from REM sleep could be reinforced by the later recovery of function in the prefrontal cortex (Balkin et al., 2002), the brain area involved in long-term memory storage.

\section{DISCUSSION}

As recalled above, the forebrain is an interdependent ensemble of structures which are subjected to numerous neurotransmitters and neuromodulators acting simultaneously at different types of receptors situated presynaptically, postsynaptically, or both; further, several types of receptors, noradrenergic in the present case, can be localized on the same target neurons with distinct activation thresholds. Moreover, a single structure, here the LC, can project to and differently influence several forebrain areas: the LC maximally influences the somatosensory cortex when tonically firing at $0.5 \mathrm{~Hz}$, whereas in the thalamic ventroposterior medial nucleus the highest sensitivity occurs at $1 \mathrm{~Hz}$ stimulation. Moreover, such LC firing inhibits the somatosensory cortex neurons in $63 \%$ of cases, whereas it activates the thalamic neurons in $65 \%$ of cases (Devilbiss and Waterhouse, 2004). Thus, interpreting the neurochemical basis of mental activities requires caution, all the more so since $31 \%$ of somatosensory cortex neurons are activated by NA.

Although today this notion has been partly questioned (Domhoff, 2007), the main characteristic of REM sleep mentation is its similarity to symptoms of schizophrenia (Gottesmann, 1999, 2005a, 2006); indeed, 11 published neurobiological properties of REM sleep (Gottesmann, 2007, 2010a) represent powerful potential endophenotypes (Gottesman and Gould, 2003) of this disease (Gottesmann and Gottesman, 2007; Gottesmann, 2010a). It is noteworthy that although some neurobiological criteria of REM sleep are also encountered in syndromes like depression and bipolar psychotic disorders, we have now identified fourteen strong similarities with schizophrenia. As confirmation of this, NA reuptake inhibiting factors are included in antipsychotic formulations (Friedman et al., 1999; Linner et al., 2002) because of the deficit of this neuromodulator in schizophrenia, although this is also the case in other conditions, particularly depression.

Moreover, NA promotes prefrontal attentional processes, and although its decrease cannot be expected to single-handedly account for dorsolateral prefrontal deactivation - which also occurs in schizophrenia, particularly when cognitive performances are impaired (Buschbaum et al., 1982; Weinberger et al., 1986; Berman et al., 1993; Fletcher et al., 1998) - the NA deficit seen in both states seems at least to be responsible for the anarchic firing of cortical pyramidal neurons (Evarts, 1964; McCormick et al., 1991). This reduced efficiency of cognitive processes during REM sleep and in schizophrenia is certainly related to the decrease in the signal/noise ratio of neuron activity. In the same way, NA favors gamma rhythm activity. The lowered NA level in both states could explain the corresponding cerebral disconnections, as shown by the disappearance of coupled gamma activity during REM sleep (see above) as well as the dysfunction in this rhythm in schizophrenia (Uhlaas and Singer, 2010), a complementary index of impaired intracerebral relations (Young et al., 1998; Meyer-Lindenberg et al., 2001, 2005; Peled et al., 2001; Kubicki et al., 2008). Moreover, in the nucleus accumbens, which is involved in the hallucinations and delusions observed in both states, the decrease in NA is, at least in part, responsible for the increased level of dopamine (Pothos et al., 1991); this occurs by disinhibition of release and loss of uptake in NA terminals (Carboni and Silvagni, 2004). Finally, in the amygdala, the lower level of NA during REM sleep disinhibits the pyramidal neurons, allowing the activated structure (see above) to excessively manifest itself, particularly by glutamate release in the nucleus accumbens; this results from deficits in prefrontal and hippocampal afferents (Grace, 2000) and promotes the threatened mental activity often encountered during dreaming and in schizophrenia.

Another possible relationship between dreaming and schizophrenia has been shown by responsiveness studies, which have demonstrated the presence of a cortical disinhibition in animals and humans that takes place during REM sleep and which could be consecutive to an NA decrease; the same disinhibition has been observed in schizophrenia by a deficit in prepulse inhibition (Kisley et al., 2003). The thalamic sensory deafferentation that occurs during REM sleep due to presynaptic inhibition of afferents, could contribute both to this sleep stage and to schizophrenic hallucinations (Behrendt and Young, 2005). The involvement of NA in thalamic transmission processes could also be hypothesized based on the difference in the sensory arousal threshold during SOREM, when it is low (Dement and Kleitman, 1957; and personal observations) while the NA level is very probably close to the waking level, and during REM sleep, when the threshold is high (see above) while NA is very low. However, mismatch negativity, an index of a kind of sensory detection, can be observed not during SWS but during SOREM (Nittono et al., 2001) and REM sleep (Sculthorpe et al., 2009), revealing a similar "pre-conscious level of processing" (Sculthorpe et al., 2009), or a kind of "protoconsciousness" (Hobson, 2009).

Finally, it is possible that the muscular atonia present during REM sleep (Jouvet and Michel, 1959; Berger, 1961; Michel et al., 1961), which is induced by lower brainstem processes (Jouvet and Mounier, 1960; Jouvet and Delorme, 1965; Henley and Morrison, 1974), conceals some symptoms of attention deficit hyperactivity disorder (ADHD), which is also related to an NA deficit (Arnsten and Dudley, 2005; Arnsten and Pliszka, 2011; Gronier, 2011). Indeed, the "vivid" mentation of REM sleep (Reeves et al., 2001), the classical jumping from one subject to another, the emotional instability, and the impulsivity, attention, and memory consolidation deficits (Prehn-Kristensen et al., 2011) are also encountered in ADHD. In both states, there is an impairment of inhibitory control processes regulating mentation and behavior, i.e., a kind of "say no" (Aston-Jones and Gold, 2009) ability deficit, which is partly related to right inferior frontal (Aston-Jones and Gold, 2009) and left dorsolateral prefrontal dysfunction (Burgess et al., 2010); both of these are concomitant to the NA decrease. While Methylphenidate, a dopamine/NA reuptake inhibitor, improves ADHD by activating prefrontal dopamine $\mathrm{D}_{1}$ as well as $\mathrm{NA} \alpha_{2 \mathrm{a}}$ receptors (Gronier, 2011) (the latter at least partly located on GABAergic interneurons: Wang et al., 2011), the more specific $\alpha_{2 a}$, agonist guanfacine, while also acting on postsynaptic $\alpha_{2 a}$ receptors in the dorsolateral prefrontal cortex (Arnsten, 2011), also improves patients with ADHD (Scahill et al., 2001; Biederman et al., 2008; Kollins et al., 2011).

Thus, partly related to the NA deficit, the dorsolateral prefrontal deactivation occurring during REM sleep, together with consecutive or simultaneous amygdala, and nucleus accumbens 
disinhibition, could provide the basis for the emotional and psychotic-like - and most often not definitively stored - dreaming activity that takes place during this sleep phase. At the same time, similar prefrontal deficits and correlative activation and disinhibition of other main cortical areas could explain the usually lively, unstable, and disorganized mental content of dreams, which is

\section{REFERENCES}

Allison, T. (1968). Recovery cycles of primary evoked potentials in cats sensorimotor cortex. Experientia 24, 240-241.

Alsene, K. M., Rajbhandari, A. K., Bamaker, M. J., and Bakshi, V. P. (2011). Discrete forebrain neuronal networks supporting noradrenergic regulation of sensorimotor gating. Neuropsychopharmacology 36, 1003-1014.

Aono, Y., Saigusa, T., Watanabe, S., Iwakami, T., Mizoguchi, N., Ikeda, H., Oshige, K., Tomiyama, K., Oi, Y., Ueda, K., Rausch, W. D., Waddington, J. L., Ito, Y., Koshikawa, N., and Cools, A. R. (2007). Role of alpha adrenoceptors in the nucleus accumbens in the control of accumbal noradrenaline efflux: a microdialysis study with freely moving rats. J. Neural Transm. 114, 1135-1142.

Arnsten, A. F. (2011). Catecholamine influences on dorsolateral prefrontal cortical networks. Biol. Psychiatry 69, e89-e99.

Arnsten, A. F., and Dudley, A. G. (2005). Methylphenidate improves prefrontal cortical cognitive function through alpha2 adrenoceptor and dopamine D1 receptor actions: relevance to therapeutic effects in attention deficit hyperactivity disorder. Behav. Brain Funct. 1, 2.

Arnsten, A. F., and Jentsch, J. D. (1997). The alpha-1 adrenergic agonist, cirazoline, impairs spatial working memory in aged monkeys. Pharmacol. Biochem. Behav. 58, 55-59.

Arnsten, A. F., and Li, B. M. (2005). Neurobiology of executive functions: catecholamine influences on prefrontal cortical functions. Biol. Psychiatry 57, 1377-1384.

Arnsten, A. F., Mathew, R., Ubriani, R., Taylor, J. R., and Li, B. M. (1999). Alpha-1noradrenergic receptor stimulation impairs prefrontal cortical cognitive function. Biol. Psychiatry 45, 26-31.

Arnsten, A. F., and Pliszka, S. R. (2011). Catecholamine influences on prefrontal cortical function: relevance to treatment of attention deficit/hyperactivity disorder and related disorders.
Pharmacol. Biochem. Behav. 99, 211-216.

Aston-Jones, G., and Bloom, F. E. (1981a). Activity of norepinephrinecontaining neurons in behaving rats anticipates fluctuations in the sleep-waking cycle. J. Neurosci. 1, 876-886.

Aston-Jones, G., and Bloom, F. E. (1981b). Norepinephrinecontaining locus coeruleus neurons in behaving rat exhibit pronounced responses to non-noxious environmental stimuli. J. Neurosci. 1, 887-900.

Aston-Jones, G., and Gold, J. I. (2009). How we say no: norepinephrine, inferior frontal gyrus, and response inhibition. Biol. Psychiatry 65, 548-549.

Balkin, T. J., Braun, A. R., Wesensten, N. J., Jeffries, K., Varga, M., Baldwin, P., Belenky, G., and Herscovitch, P. (2002). The process of awakening: a PET study of regional brain activity patterns mediating the re-establishment of alertness and consciousness. Brain 125, 2308-2319.

Behrendt, R. P., and Young, C. (2005). Hallucinations in schizophrenia, sensory impairment and brain disease: an unified model. Behav. Brain Sci. 27, 771-787.

Berger, R. (1961). Tonus of extrinsic laryngeal muscles during sleep and dreaming. Science 134, 840.

Berger, R. J., and Oswald, I. (1962). Eye movements during active and passive dreams. Science 137, 601 .

Berlucchi, G. (1997). One or many arousal system? Reflections on some of Guiseppe Moruzzi's foresights and insights about intrinsic regulation of brain activity. Arch. Ital. Biol. 135, 5-14.

Berman, K. F., Doran, A. R., Pickar, D., and Weinberger, D. R. (1993). Is the mechanism of prefrontal hypofunction in depression the same as in schizophrenia? Regional cerebral blood flow during cognitive activation. Br. J. Psychiatry 162, 183-192.

Berridge, C. W., Page, M. E., Valentino, R. J., and Foote, S. L. (1993). Effects of locus coeruleus inactivation on electroencephalographic activity in neocortex and hippocampus. $\mathrm{Neu}$ roscience $55,381-393$. also observed in ADHD: "deficits in prefrontal cortex function are evident in most neuropsychiatric disorders" (Ramos and Arnsten, 2007).

\section{ACKNOWLEDGMENTS}

I thank Dr. P. Follette for improving the English of the manuscript.
Berridge, C. W., and Waterhouse, B. D. (2003). The locus coeruleusnoradrenergic system: modulation of behavioral state and statedependent cognitive processes. Brain Res. Rev. 42, 33-84.

Biederman, J., Melmed, R. D., McBurnett, K., Donahue, J., and Lyne, A. (2008). Long-term, open-label extension study of guanfacine extended release in children and adolescents with ADHD. CNS Spectr. 13, 1047-1055.

Bonjean, M., Baker, T., Lemieux, M. Timofeev, I., Sejnowski, T. J., and Bazhenov, M. (2011). Corticothalamic feedback controls sleep spindle duration in vivo. J. Neurosci. 31, 9124-9134.

Bosinelli, M. (1995). Mind and consciousness during sleep. Brain Res. 69, 195-201.

Bouret, S., Duvel, A., Onat, S., and Sara, S. J. (2003). Phasic activation of locus coeruleus neurons by the central nucleus of the amygdala. $J$. Neurosci. 23, 3491-3497.

Bouret, S., and Sara, S. J. (2005). Network reset: a simplified overarching theory of locus coeruleus noradrenaline function. Trends Neurosci. 28 , 574-582.

Brake, W. G., Flores, G., Francis, D., Meaney, M. J., Srivastava, L. K., and Gratton, A. (2000). Enhanced nucleus accumbens dopamine and plasma corticosterone stress responses in adult rats with neonatal excitotoxic lesions to the medial prefrontal cortex. Neuroscience 96, 687-695.

Braun, A. R., Balkin, T. J., Wesensten, N. J., Carson, R. E., Varga, M., Baldwin, P., Selbie, S., Belenky, G., and Herscovitch, P. (1997). Regional cerebral blood flow throughout the sleepwake cycle: an 150 PET study. Brain 120, 1173-1197.

Braun, A. R., Balkin, T. J., Wesensten, N. J., Gwardry, f., Carson, R. E., Varga, M., Baldwin, P., Belenky, G., and Herscovitch, P. (1998). Dissociated pattern of activity in visual cortices and their projections during human rapid eye movement sleep. Science 279, 91-95.

Buffalari, D. M., and Grace, A. A. (2007). Noradrenergic modulation of basolateral amygdala neuronal activity: opposing influences of alpha-2 and beta receptor activation. J. Neurosci. 27, 12358-12366.

Burgess, G. C., Depue, B. E., Ruzic, L., Willcutt, E. G., Du, Y. P. and Banich, M. T. (2010). Attentional control activation relates to working memory in attention-deficit/hyperactivity disorder. Biol. Psychiatry 67, 632-640.

Buschbaum, M. S., Ingvar, D. H., Kessler, R., Waters, R. N., Cappelletti, J., Van Kammen, D. P., King, A. C., Johnson, J. L., Manning, R. G., Flynn, R. W., Bunney, W. E. J., and Sokoloff, L. (1982). Cerebral glucography with positron tomography, use in normal subjects and in patients with schizophrenia. Arch. Gen. Psychiatry 39, 251-259.

Cadilhac, J., Passouant-Fontaine, T., and Passouant, P. (1961). Modifications de l'activité de l'hippocampe suivant les divers stades du sommeil spontané chez le Chat. Rev. Neurol. 105, 171-176.

Callaway, C. W., and Henriksen, S. I. (1992). Neuronal firing in the nucleus accumbens is associated with the level of cortical arousal. Neuroscience 51, 547-553.

Cantero, J. L., Atienza, M., Madsen, J. R., and Stickgold, R. (2004). Gamma EEG dynamics in neocortex and hippocampus during human wakefulness and sleep. Neuroimage 22, 1271-1280.

Carboni, E., and Silvagni, A. (2004). Dopamine reuptake by norepinephrine neurons: exception or rule? Crit. Rev. Neurobiol. 16, 121-128.

Castro-Alamancos, M. A., and Calcagnotto, M. E. (2001). Highpass filtering of corticothalamic activity by neuromodulators released in the thalamus during arousal: in vitro and in vivo. $J$. Neurophysiol. 85, 1489-1497.

Cavallero, C. (2003). "REM sleep = dreaming: the never-ending story," in Sleep and Dreaming. Scientific Advances and Reconsideration, eds E. Pace-Schott, M. Solms, M. Blagrove, and S. Harnard (Cambridge: Cambridge University Press), 127-128.

Cavallero, C. P. Cicogna, V., Natale, M., and Occhionero, A. Z. (1992). Slow wave sleep dreaming. Sleep 15 , 562-566. 
Cecchi, M., Khoshbouei, H., and Morilak, D. A. (2002). Modulatory effects of norepinephrine, acting on alpha 1 receptors in the central nucleus of the amygdala, on behavioral and neuroendocrine response to acute immobilization stress. Neuropharmacology 43, 1139-1147.

Cespuglio, R., Houdouin, F., Oulerich, M., El Mansari, M., and Jouvet, M. (1992). Axonal and somatodendritic modalities of serotonin release: their involvement in sleep regulation, triggering and maintenance. J. Sleep Res. 1, 150-156.

Chen, F. J., and Sara, S. J. (2007). Locus coeruleus activation by foot shock or electrical stimulation inhibits amygdala neurons. Neuroscience 144, 472-481.

Chiodo, L. A., Acheson, A. L., Zigmond, M. J., and Stricker, E. M. (1983). Subtotal destruction of central noradrenergic projections increases the firing rate of locus coeruleus cells. Brain Res. 264, 123-126.

Corsi-Cabrera, M., Miro, E., del Rio Portilla, Y., Perez-Garci, E., Villanueva, Y., and Guevera, M. (2003). Rapid eye movement sleep dreaming is characterized by uncoupled EEG activity netween frontal abd perceptual cortical regions. Brain Cogn. 51, 337-345.

Dagnino, N., Favale, E., Loeb, C., Manfredi, M., and Seitun, A. (1969). Presynaptic and postsynaptic changes in specific thalamic nuclei during deep sleep. Arch. Ital. Biol. 107, 668-684

Delfs, J. M., Zhu, Y., Druhan, J. P., and Aston-Jones, G. S. (1998). Origin of noradrenergic afferents to the shell subregion of the nucleus accumbens: anterograde and retrograde tracttracing studies in the rat. Brain Res. 806, 127-140.

Dement, W., and Kleitman, N. (1957). Cyclic variations in EEG during sleep and their relation to eye movements, body motility, and dreaming. Electroencephalogr. Clin. Neurophysiol.9, 673-690.

Dement, W., and Wolpert, E. A. (1958). The relation of eye movements, body motility, and external stimuli to dream content. J. Exp. Psychol. 55, 543-553.

Dement, W. C. (1958). The occurrence of low voltage fast electroencephalogram patterns during behavioral sleep in the cat. Electroencephalogr. Clin. Neurophysiol. 10, 291-296.

Dement, W. C. (1965). Dreams and dreaming. Int. J. Neurol. 5, 168-186.

Descarries, L., Watkins, K. C., and Lapierre, Y. (1977). Noradrenergic axon terminals in the cerebral cortex of rats III. Topometric ultrastructural analysis. Brain Res. 133, 197-222.

Devilbiss, D. M., Page, M., and Waterhouse, B. D. (2006). Locus coeruleus regulates sensory encoding by neurons and networks in waking animals. J. Neurosci. 26, 9860-9872.

Devilbiss, D. M., and Waterhouse, B. D. (2004). The effects of tonic locus coeruleus output on sensoryevoked responses of ventral posterior medial thalamus and barrel field cortical neurons in the awake rat. J. Neurosci. 24, 10773-10785.

Domhoff, G. W. (2007). "Realistic stimulation and bizarreness in dream content: past findings and suggestions for future research," in The New Science of Dreaming, Vol. 2, eds D. Barrett and P. McNamara (Westport: Praeger), 1-27.

Euston, D. R., Tatsuno, M., and McNaughton, B. L. (2007). Fastforward playback of recent memory sequences in prefrontal cortex during sleep. Science 318, 1147-1150.

Evarts, E. V. (1964). Temporal patterns of discharge of pyramidal tract neurons during sleep and waking in the monkey. J. Neurophysiol. 27, 152-171.

Fenik, V., Marchenko, V., Janssen, P. davies, R. O., and Kubin, L. (2002). A5 cells are silenced when REM sleep-like signs are elicited by pontine carbachol. J. Appl. Physiol. 93, 1448-1456.

Ferry, B., and McGaugh, J. L. (2008). Involvement of basolateral amygdala alpha adrenoreceptors in modulating consolidation of inhibitory avoidance memory. Learn. Mem. 15, 238-243.

Ferry, B., Roozendaal, B., and McGaugh, J. L. (1999). Basolateral amygdala noradrenergic influences on memory storage are mediated by an interaction between beta- and alphaladrenoreceptors. J. Neurosci. 19, 5119-5123.

Fletcher, P. C., McKenna, P. J., Frith, C. D., Grasby, P. M., Friston, K. J., and Dolan, R. J. (1998). Brain activation in schizophrenia during a graded memory task studied with functional neuroimaging. Arch. Gen. Psychiatry 55, 1001-1008.

Floresco, S. B., Yang, C. R., Phillips, A. G., and Blaha, C. D. (1998). Basolateral amygdala stimulation evokes glutamate receptor-dependent dopamine efflux in the nucleus accumbens of the anesthetized rat. Eur. J. Neurosci. 10, 1241-1251.

Foote, S. L., Freedman, R., and Oliver, A. P. (1975). Effects of putative neurotransmitters on neuronal activity on monkey auditory cortex. Brain Res. $86,229-242$.
Foulkes, W. D. (1962). Dream reports from different stages of sleep. J. Abnorm. Soc. Psychol. 65, 14-25.

Foulkes, W. D., and Vogel, G. (1965). Mental activity at sleep onset. J. Abnorm. Psychol. 70, 231-243.

Franowicz, J. S., Kessler, L., Morgan, C. and Arnsten, A. F. T. (1998). The alpha-2 noradrenergic, guanfacine, improves spatial working memory in wild type mice but not mice with point mutations of the gene for the alpha-2A receptor. Abstr. Soc. Neurosci. 24, 711. [quoted by Ramos and Arnsten 2007].

Frederickson, R. C. A., Jordan, L. M. and Phillis, J. W. (1971). The action of noradrenaline on cortical neurons: effects of pH. Brain Res. 35 , 556-560.

Freud, S. (1911). Formulations on the Two Principles of Mental Functioning Vol. XII, ed. S. Edition. London: The Hogarth Press.

Friedman, J. I., Adler, D. N., and Davis, K. L. (1999). The role of norepinephrine in the physiopathology of cognitive disorders: potential applications to the treatment of cognitive dysfunction in schizophrenia and Alzheimer's disease. Biol. Psychiatry 46, 1243-1252.

Fuxe, K., Hamberger, B., and Hökfelt, T. (1968). Distribution of noradrenaline nerve terminals in cortical areas in the rat. Brain Res. 8, 125-131.

Gais, S., Rasch, B., Dahmen, J. C., and Born, J. (2011). The memory function of noradrenergic activity in Non-REM sleep. J. Cogn. Neurosci. 23, 2582-2592.

Gandolfo, G., Arnaud, C., and Gottesmann, C. (1980). Transmission in the ventrobasal complex of rat during the sleep-waking cycle. Brain Res. Bull. 5, 921-927.

Ghelarducci, B., Pisa, M., and Pompeiano, M. (1970). Transformation of somatic afferent volleys across the prethalamic and thalamic components of the lemniscal sytem during the rapid eye movements of sleep. Electroencephalogr. Clin. Neurophysiol. 29, 348-357.

Glin, L., Zernicki, B., and Gottesmann, C. (1991). Hippocampal and cortical EEG activity in rats with transected hypothalamus. Brain Res. Bull. 27, 637-640.

Gottesman, I. I., and Gould, T. D. (2003). The endophenotype concept in psychiatry: etymology and strategic intentions. Am. J. Psychiatry 160, 636-645.

Gottesmann, C. (1999). Neurophysiological support of consciousness during waking and sleep. Prog. Neurobiol. 59, 469-508.

Gottesmann, C. (2000). Each different type of mentation is supported by specific brain functioning. Behav. Brain Sci. 23, 941-943.

Gottesmann, C. (2001). The golden age of rapid eye movement sleep discoveries. I. Lucretius-1964. Prog. Neurobiol. 65, 211-287.

Gottesmann, C. (2005a). Dreaming and schizophrenia. A common neurobiological background. Sleep Biol. Rhythms 3, 64-74.

Gottesmann, C. (2005b). The Golden Age of Rapid Eye Movement Sleep Discoveries: 1965-1966. New York: Nova Science Publishers, Inc.

Gottesmann, C. (2006). The dreaming sleep stage: a new neurobiological model of schizophrenia? Neuroscience 140, 1105-1115.

Gottesmann, C. (2007). Schizophrenia: a conjectured daytime psychobiological invasion by rapid eye movement (REM) sleep. Schizophr. Res. Available at: http://www.schizophreniaforum.org/ idea/idealab-print.asp

Gottesmann, C. (2008). Noradrenaline involvement in basic and higher integrated REM sleep processes. Prog. Neurobiol. 82, 237-272.

Gottesmann, C. (2010a). The development of the science of dreaming. Int. Rev. Neurobiol. 92, 1-29.

Gottesmann, C. (2010b). To what extent do neurobiological sleepwaking processes support psychoanalysis. Int. Rev. Neurobiol. 92, 233-290.

Gottesmann, C., and Gottesman, I. I. (2007). The neurobiological characteristics of the rapid eye movement (REM) dreaming sleep stage are candidate endophenotypes of depression, schizophrenia, mental retardation and dementia. Prog. Neurobiol. 81, 237-250.

Gottesmann, C., User, P., and Gioanni, H. (1980). Sleep: a physiological cerveau isolé stage? Waking Sleeping 4, 111-117.

Grace, A. A. (2000). Gating information flow within the limbic system and the pathophysiology of schizophrenia. Brain Res. Rev. 31, 330-341.

Green, J. D., and Arduini, A. (1954). Hippocampal electrical activity in arousal. Electroencephalogr. Clin. Neurophysiol. 17, 532-557.

Greene, C. M., Bellgrove, M. A., and Robertson, I. H. (2009). Noradrenergic genotype predicts lapses in sustained attention. Neuropsychologia 47, 591-594.

Groch, S., Wilhelm, I., Diekelman, S., Sayk, F., Gais, S. and Born, J. (2011). Contribution of norepinephrine to emotional memory consolidation during sleep. Psychoneuroendocrinology 36, 1342-1350. 
Gronier, B. (2011). In vivo electrophysiological effects of methylphenidate in the prefrontal cortex: involvement of dopamine D1 and alpha 2 adrenergic receptors. Eur. Neuropsychopharmacol. 21, 192-204.

Gulyani, S., Wu, M. F., Nienhuis, R., John, J., and Siegel, C. . (2002). Cataplexy-related neurons in the amygdala of the narcoleptic dog. Neuroscience 112, 355-365.

Hajos, M., Hoffmann, W. E., Robinson, D. D., Yu, J. H., and Hajos-Korcsok, E. (2003). Norepinephrine but not serotonin reuptake inhibitors enhance theta and gamma activity of the septo-hippocampal system. Neuropschopharmacology 28, 857-864.

Henley, K., and Morrison, A. R. (1974). A re-evaluation of the effects of lesions of the pontine tegmentum and locus coeruleus on phenomena of paradoxical sleep in the cat. Acta Neurobiol. Exp. (Wars) 34, 215-232.

Hennevin, E., Hars, B.,Maho, C., and Bloch, V. (1995). Processing of learning:information in paradoxical sleep: relevance for memory. Behav. Brain Res. 69, 125-135.

Hennevin, E., Huetz, C., and Edeline, J. M. (2007). Neural representations during sleep: from sensory processing to memory traces. Neurobiol. Learn. Mem. 87, 416-440.

Hess, C., Reif, A., Boreatti-Hümmer, A., Heine, M., Lesch, K. P., and Jacob, C. P. (2009). A functional dopamine beta-hydroxylase gene promoter polymorphism is associated with impulsive personality styles but not with affective disorders. J. Neural Transm. 116, 121-130.

Hobson, J. A. (2009). REM sleep and dreaming: towards a theory of protoconsciousness. Nat. Rev. Neurosci. 10, 803-813.

Hobson, J. A., McCarley, R. W., and Wyzinski, P. W. (1975). Sleep cycle oscillation: reciprocal discharge by two brainstem neuronal groups. Science $189,55-58$.

Hobson, J. A., Pace-Schott, E., and Stickgold, R. (2000). Dreaming and the brain: towards a cognitive neuroscience of conscious states. Behav. Brain Sci. 23, 793-842.

Hong, C. C. H., Gillin, J. C., Dow, B. C., Wu, J., and Buschbaum, M. S. (1995). Localized and lateralized cerebral glucose metabolism associated with eye movements during REM sleep and wakefulness: a positron emission tomography (PET) study. Sleep $18,570-580$

Hong, C. C. H., Harris, J. C., Pearlson, G. D., Kim, J.-S., Calhoun, V. C., Fallon, J. H., Golay, X., Gillen, J. S., Simmonds, D. J., van Zijl, P. C. M., Zee, D. S., and Pekar, J. J.
(2009). fMRI evidence for multisensory recruitment associated with rapid eye movements during sleep. Hum. Brain Mapp. 30, 1705-1722.

Hurlemann, R., Walter, H., Rehme, A. K., Kukolja, J., Santoro, S. C., Schmidt, C., Schnell, K., Musshof, F., Keysers, C., Maier, W., Kendrick, K. M. and Onur, O. A. (2010). Human amygdala reactivity is diminished by the b-noradrenergic antagonist propanolol. Psychol. Med. 40, 1839-1848.

Iwama, K., Kawamoto, T., Sakkakura, H., and Kasamatsu, T. (1966). Responsiveness of cat lateral geniculate at pre- and post-synaptic levels during natural sleep. Physiol. Behav. 1, 45-53.

Jackson, M. E., Frost, A. S., and Moghaddam, B. (2001). Stimulation of prefrontal cortex at physiologically relevant frequencies inhibits dopamine release in nucleus accumbens. $J$. Neurochem. 78, 920-923.

Jha, S. K., Ross, R. J., and Morrison, A. R. (2005). Sleep-related neurons in the central nucleus of the amygdala of rats and their modulation by the dorsal raphe nucleus. Physiol. Behav. 86, 415-426.

Ji, D., and Wilson, M. (2007). Coordinated memory replay in the visual cortex and hippocampus during sleep. Nat. Neurosci. 10, 100-107.

Jodo, E., Chiang, C., and Aston-Jones, G. (1998). Potent excitatory influence of prefrontal cortex activity on noradrenergic locus coeruleus. Neuroscience 83, 63-79.

Johnson, J. D. (2003). Noradrenergic control of cognition: global attenuation and an interrupt function. Med. Hypotheses 60, 689-692.

Jouvet, M., and Delorme, F. (1965). Locus coeruleus et sommeil paradoxal. C. R. Seances Soc. Biol. Fil. 159, 895-899.

Jouvet, M., and Michel, F. (1959). Corrélations électromyographiques du sommeil chez le Chat décortiqué et mésencéphalique chronique. C. $R$. Seances Soc. Biol. Fil. 153, 422-425.

Jouvet, M., and Mounier, D. (1960). Effets des lésions de la formation réticulaire pontique sur le sommeil du Chat. C. R. Seances Soc. Biol. Fil. 154, 2301-2305.

Jung, R., and Kornmüller, A. E. (1938). Eine Methodik der Abteilung lokalisierter Potentialschwankungen aus subcorticalen Hirngebieten. Arch. Psychiatr. Nervenkr. 109, 1-30.

Kaneko, K., Tamamaki, N., Owada, H., Kakizaki, T., Kuma, N., Totsuka, M., yamamoto, T., Yawo, H., Yagi, T., Obata, K., and Yanagawa, Y. (2008). noradrenergic excitation of a subpopulation of GABAergic cells in the basolateral amygdala via both activation of nonselective cationic conductance and suppression of resting $\mathrm{K}+$ conductance: a study using glutamate decarboxylase 67-green fluorescent protein knock-in mice. $\mathrm{Neu}$ roscience 157, 781-797.

Kieling, C., Genro, J. P., Hurtz, M. H., and Rohde, I. A. (2008). The $1021 \mathrm{C} / \mathrm{T}$ polymorphism is associated with neuropsychological performance among children and adolescents with ADHD. Am. J. Med. Genet. B Neuropsychiatr. Genet. 147B, 485-490.

Kisley, M. A., Olincy, A., Robbins, E. Polk, S. D., Adler, L. E., Waldo, M. C., and Freedman, R. (2003). Sensory gating impairement associated with schizophrenia persists into REM sleep. Psychophysiology 40 29-38.

Kollins, S. H., Lopez, F. A., Vince, B. D., Tumbow, J. M., Farrand, K., Lyne, A., Wigal, S. B., and Roth, T. (2011). Psychomotor functioning and alertness with guanfacine extended release in subjects with attention-deficit/hyperactivity disorder. J. Child Adolesc. Psychopharmacol. 21, 111-120.

Krnjevic, K., and Phillis, J. W. (1963). Actions of certain amines on cerebral cortex neurons. Br. J. Pharmacol. 20, 471-490.

Kubicki, M., Styner, M., Gerig, G., Markant, D., Smith, K., MacCarley, R. W., and Shenton, M. E. (2008). Reduced interhemispheric connectivity in schizophrenic-tractography based segmentation of the corpus callosum. Schizophr. Res. 106, 125-131.

Kubota, Y., Takasu, N. N., Horita, S., Kondo, M., Shimizu, M., Okada, T., Wakamura, T., and Tolchi, M. (2011). Dorsolateral prefrontal cortical oxygenation during REM sleep in humans. Brain Res. 1389, 83-92.

Kukolja, J., Klingmüller, D., Maier, W., Fink, G. R. and Hurlemann, R. (2011). Noradrenergicglucocorticoid modulation of emotional memory encoding in the human hippocampus. Psychol. Med. 4, 1-10.

Lazzaro, S. C., Hou, M., Cunha, C. LeDoux, J. E., and Cain, C. K. (2010). Antagonism of lazteral amygdala alpha-1 adrenergic receptors facilitates fear conditioning and longterm potentiation. Learn. Mem. 17, 489-493.

Leconte, P., and Hennevin, E. (1981). Post-learning paradoxical sleep, reticular activation and noradrenergic activity. Physiol. Behav. 26, 587-594.
Léna, I., Parrot, S., Deschaux, O., Muffat, S., Sauvinet, V., Renaud, B., SuaudChagny, M. F., and Gottesmann, C. (2005). Variations in the extracellular levels of dopamine, noradrenaline, glutamate and aspartate across the sleep-wake cycle in the medial prefrontal cortex and nucleus accumbens of freely moving rats. $J$. Neurosci. Res. 81, 891-899.

Libet, B., and Gleason, G. A. (1994). The human locus coeruleus and anxiogenesis. Brain Res. 634, 178-180.

Linner, L., Wiker, C., Wadenberg, M. L., Schalling, M., and Svensson, T. H. (2002). Noradrenaline reuptake inhibition enhances the antipsychotic-like effect of raclopride and potentiates D2-blockadeinduced dopamine release in the medial prefrontal cortex of the rat. Neuropsychopharmacology 27, 691-698.

Lipska, B. K., Jaskiw, G., and Weinberger, D. R. (1993). Postpubertal emergence of hyperresponsiveness to stress and to amphetamine after neonatal excitotoxic hippocampal damage: a potential animal model of schizophrenia. Neuropsychopharmachology 9, 67-75.

Llinas, R., and Ribary, U. (1993). Coherent $40 \mathrm{~Hz}$ oscillation characterizes dream state in humans. Proc. Natl. Acad. Sci. U.S.A. 90, 2078-2081.

MacKay, A. V., Iversen, L. L., Rossor, M., Spokes, E., Bird, E., Arregui, A., and Snyder, S. (1982). Increased brain dopamine and dopamine receptors in schizophrenia. Arch. Gen. Psychiatry 39, 991-997.

Malcolm-Smith, S., Solms, M., Turnbull, O., and Tredoux, C. (2007). Threat in dreams: an adaptation. Conscious. Cogn. 17, 1281-1291.

Manacéine, M. d. (1897). Sleep: Its Physiology, Pathology, Hygiene, and Psychology. London: Walter Scott.

Manunta, Y., and Edeline, J. M. (1999). Effects of noradrenaline on frequency tuning of auditory cortex neurons during wakefulness and slow wave sleep. Eur. J. Neurosci. 11, 2134-2150.

Mao, Z. M., Arnsten, A. F., and Li, B. M. (1999). local infusion of an alpha1 adrenergic agonist into the prefrontal cortex impairs spacial working memory performance in monkeys. Biol. Psychiatry 46, 1259-1265.

Maquet, P., and Franck, G. (1997). REM sleep and amygdala. Mol. Psychiatry 2, 195-196.

Maquet, P., Peters, J. M., Aerts, J., Delfiore, G., Degueldre, C. and Luxen, A., and Franck, G. (1996). Functional neuroanatomy of human rapid-eye-movement sleep and dreaming. Nature 383, 163-166. 
Marrosu, F., Portas, C., Mascia, M. F., Casu, M. A., Fa, M., Giagheddu, M., Imperato, A., and Gessa, G. L. (1995). Microdialysis measurement of cortical and hippocampal acetylcholine release during sleep-wake cycle in freely moving cats. Brain Res. 671, 329-332.

Massimini, M., Ferrarelli, F., Huber, R., Esser, S. K., Singh, H., and Tononi, G. (2005). Breakdown of cortical effective connectivity during sleep. Science 309, 2228-2232.

McCormick, D. A., and Krosigk, V. M. (1992). Corticothalamic activation modulates thalamic firing through glutamate "metabotropic" receptors. Proc. Natl. Acad. Sci. U.S.A. 89, 2774-2778.

McCormick, D. A., Pape, H. C., and Williamson, A. (1991). Actions of norepinephrine in the cerebral cortex and thalamus: implications for function of the central noradrenergic system. Prog. Brain Res. 88, 293-305.

McCormick, D. A., Wang, Z., and Huguenard, J. (1993). Neurotransmitter control of neocortical neuronal activity and excitability. Cereb. Cortex 3, 387-398.

McGaughy, J., Ross, R. S., and Eichenbaum, H. (2008). Noradrenergic, but not cholinergic, deafferentation of prefrontal cortex impairs emotional set-shifting. Neuroscience 153, 63-71.

Meyer-Lindenberg, A., Olsen, R. K., Kohn, P. D., Brown, T., Egan, M. F., Weinberber, D. R., and Berman, K. F. (2005). Regionally specific disturbance of dorsolateral prefrontalhippocampal function connectivity in schizophrenia. Arch. Gen. Psychiatry 62, 379-386.

Meyer-Lindenberg, A., Poline, J. B., Kohn, P. D., Holt, J. L., Egan, M. F., Weinberger, D. R., and Berman, K. F. (2001). Evidence for abnormal cortical functional connectivity during working memory in schizophrenia. Am. J. Psychiatry 158, 1809-1817.

Michel, F., Klein, M., Jouvet, D., and Valatx, J. L. (1961). Etude polygraphique du sommeil chez le Rat. C. R. Seances Soc. Biol. Fil. 155, 2389-2392.

Milstein, J. A., Lehmann, O., Theobald, D. E., Dalley, J. W., and Robbins, E. (2007). Selective depletion of cortical noradrenaline by antidomaine beta-hydroxylase-saporin impairs attentional function and enhances the effect of guafacine in the rat. Psychopharmacology 190, 51-63.

Misoguchi, N., Saigusa, T., Aono, Y., Sekino, R., Takada, K., Oi, Y., Ueda,
K., Koshikawa, N., and Cools, A. R. (2008). The reboxetine-induced increase of accumbal dopamine efflux is inhibited by l-propranolol: a microdialysis study with freely moving rats. Eur. J. Pharmacol. 601, 94-98.

Miyajima, M., Ozaki, M., Wada, K., and Sekiguchi, M. (2010). Noradrenaline-induced spontaneous inhibitory postsynaptic currents in mouse basolateral nucleus of amygdala pyramidal neurons: comparison with dopamine-induced currents. Neurosci. Lett. 480, 167-172.

Miyauchi, S., Misaki, M., Kan, S., Fukunaga, T., and Koike, T. (2009). Human brain activity time-locked to rapid eye movements during REM sleep. Exp. Brain Res. 192, 657-667.

Montgomery, S. M., Sirota, A., and Buzsaki, G. (2008). Theta and gamma coordination of hippocampal networks during waking and rapid eye movement sleep. J. Neurosci. 28, 6731-6741.

Morrison, A. R., and Pompeiano, O. (1966). Vestibular influences during sleep. IV. Functional relations between vestibular nuclei and lateral geniculate nucleus during desynchronized sleep. Arch. Ital. Biol. 104, 425-458.

Murchison, C. F., Schutsky, K., Jin, S. H., and Thomas, S. A. (2011). Norepinephrine and beta (1)-adrenergic signaling facilitate activation of hippocampal CA1 pyramidal neurons during contextual memory retrieval. Neuroscience 181, 109-116.

Nelson, C. N., Hoffer, B. J., Chu, N. S., and Bloom, F. E. (1973). Cytochemical and pharmacological studies on polysensory neurons in the primate frontal cortex. Brain Res. 62, 115-133.

Nielsen, J. B. (2003). "A review of mentation in REM and NREM sleep: 'covert' REM sleep as a possible reconciliation of two opposing models," in Sleep and Dreaming. Scientific Advances and Reconsiderations, eds E. Pace-Schott, M. Solms, M. Blagrove, and S. Harnad (Cambridge: Cambridge University Press), 59-74.

Nittono, H., Momose, D., and Hori, T. (2001). The vanishing point of the mismatch negativity at sleep onset. Clin. Neurophysiol. 112, 732-739.

Olmstead, C. E., and Villablanca, J. (1977). Hippocampal theta rhythm persists in the permanently isolated forebrain of the cat. Brain Res. Bull. 2, 93-100.

Park, S. P. (2002). In vovo microdialysis measures of extracellular norepinephrine in the rat amygdala during sleep-wakefulness. J. Korean Med. Sci. 17, 395-399.

Peigneux, P., Laurey, S., Fuchs, S., Destrebecqz, A., Collette, F., Delbeuck, X., Phillips C, Aerts, J., Del Flore, G, Delguedre, C., Luxen, A., Cleeremans, A., and Maquet, P. (2003). Learned material content and acqisition level modulate cerebral reactivation during postraining rapid-eye-movement sleep. $\mathrm{Neu}$ roimage 20, 125-134.

Peled, A., Geva, A. B., Kremen, W. S., Blankfeld, H. M., Esfandiarfard, R., and Nordahl, T. E. (2001). Functional connectivity and working memory in schizophrenia: an EEG study. Int. J. Neurosci. 106, 47-61.

Perez-Garci, E., del Rio-Portilla, Y., Guevara, M. A., Arce, C., and CorsiCabrera, M. (2001). Paradoxical sleep is characterized by uncoupled gamma activity between frontal and perceptual cortical regions. Sleep 24, 118-126.

Pothos, E., Rada, P., Mark, G. P., and Hoebel, B. G. (1991). Dopamine microdialysis in the nucleus accumbens during acute and chronic morphine, naloxone-precipited withdrawal and clonidine treatment. Brain Res. 566, 348-350.

Prehn-Kristensen, A., Göder, R., Fischer, J., Wilhelm, I., Seeck-Hirschner, M. Aldenhoff, J., and Baving, L. (2011). Reduced sleep-associated consolidation of declarative memory in attention-deficit/hyperactivity disorder. Sleep Med. 12, 672-679.

Radwanska, K., Nikolaev, E., and Kaczmarek, L. (2010). Central noradrenergic lesion induced by DSP-4 impairs the acquisition of avoidance reactions and prevents molecular changes in the amygdala. Neurobiol. Learn. Mem. 94, 303-311.

Ramos, B. P., and Arnsten, A. F. T. (2007). Adrenergic pharmacology and cognition: focus on the prefrontal cortex. Pharmacol. Ther. 113, 523-536.

Ramos, B. P., Colgan, L., Ovadia, S., Wilson, S. R., and Arnsten, A. F. (2005). The beta-1 adrenergic antagonist, betaxolol, improves working memory performance in rats and monkeys. Biol. Psychiatry 58, 894-900.

Rasmussen, K., Morilak, D. A., and Jacobs, B. L. (1986). Single unit activity of locus coeruleus neurons in the freely moving cat I. Naturalistic behaviors and in response to simple and complex stimuli. Brain Res. 371, 324-334.

Reader, T. A., Ferron, A., Descarries, L. and Jasper, H. H. (1979). Modulatory role for biogenic amines in the cerebral cortex. Microiontopheric studies. Brain Res. 160, 219-229.

Rechtschaffen, A., Vogel, G., and Shaikun, G. (1963). Interelatedness of mental activity during sleep. Arch. Gen. Psychiatry 9, 536-547.

Reeves, M., Lindholm, D. E., Myles, P. S., Fletcher, H., and Hunt, J. O. (2001). Adding ketamine to morphine for patient-controlled analgesia after major abdominal surgery: a double-blind, randomized trial. Anesth. Analg. 93, 116-120.

Reich, H., Ruppecht, U., Stumpf, H., and Stock, G. (1983). Modulation of unit activity in the amygdala of restrained cats during the sleep-waking cycle. Neurosci. Lett. 35, 209-214.

Revonsuo, A. (2003). "The reinterpretation of dreams: an evolutionary hypothesis of the function of dreaming," in Sleep and Dreaming. Scientific Advances and Reconsiderations, eds E. Pace-Schott, M. Solms, M. Blagrove, and S. Harnad (Cambridge: Cambridge University Press), 85-109.

Rossi, G. F., Palestini, M., Pisano, M., and Rosadini, G. (1965). "An experimental study of the cortical reactivity during sleep and wakefulness," in Aspects anatomo-fonctionnels de la physiologie $d u$ sommeil (Paris: CNRS), 509-532.

Sakakura, H., and Iwama, K. (1965). Presynaptic inhibition and postsynaptic facilitation in lateral geniculate body and so-called deep sleep wave activity. Tohoku J. Exp. Med. 87, 40-51.

Scahill, L., Chappell, P. B., Kim, Y. S., Schultz, R. T., Katsovitch, L., Shepperd, E., Arnsten, A. F., Cohen, D. J., and Leckman, J. F. (2001). A placebocontrolled study of guanfacine in the treatment of children with tic disorders and attention deficit hyperactivity disorder. Am. J. Psychiatry 158, 1067-1074.

Sculthorpe, L. D., Ouellet, D. R., and Campell, K. B. (2009). MMN elicitation during natural sleep to violations of an auditory pattern. Brain Res. 1290, 52-62.

Segal, M. (1974). The action of norepinephrine in the rat hippocampus. I. Iontophoretic studies. Brain Res. 72, 79-97.

Segal, M. (1981). Regional differences in neuronal responses to 5-HT: intracellular studies in hippocampal slices. J. Physiol. Paris 77, 373-375.

Segal, M. (1990). Potassium currents activated in hippocampal neurons by serotonin are mediated by a change in intracellular calcium concentrations. Eur. J. Pharmacol. 181, 299-301. 
Segal, M., and Bloom, F. E. (1976). The action of norepinephrine in the rat hippocampus. III. Hippocampal cellular responses to locus coeruleus stimulation in the awake rat. Brain Res. 107, 499-551.

Seguela, P., Watkons, K. C., Geffard, M., and Descarries, L. (1990). Noradrenaline axon terminals in adult rat neocortex: an immunocytochemical analysis in serial thin sections. Neuroscience 35, 249-264.

Selden, N. R. W., Robbins, T. W., and Everitt, B. J. (1990). Enhanced behavioral conditioning to context and impaired behavioral and neuroendocrine responses to conditioned stimuli following ceruleocortical noradrenergic lesions: support for an attentional hypothesis of central noradrenergic function. $\mathrm{J}$. Neurosci. 10, 531-539.

Shouse, M. N., Staba, R. J., Saquib, S. F., and Farber, P. R. (2000). Monoamines and sleep: microdialysis findings in pons and amygdala. Brain Res. 860, 181-189.

Siegel, J. M. (2001). The REM sleep memory consolidation hypothesis. Science 294 1058-1063.

Smith, C. (1995). Sleep states and memory processes. Behav. Brain Res. 69, 137-145.

Smith, C., and Lapp, L. (1991). Increases in number of REMS and REM density in humans following an intense learning period. Sleep 14, 325-330.

Steere, J. C., and Arnsten, A. F. (1997). The alpha-2 noradrenergic receptor agonist guanfacine improves visual object discrimination reversal performance in aged rhesus monkeys. Behav. Neurosci. 111, 883-891.

Stegeren van, A. H., Goekoop, R., Everaerd, W., Scheltens, P., Barkhof, F., Kuijer, J. P., and Trombouts, S. A. (2005). Norasrenaline mediates amygdala activation in men and women during encoding of emotional material. Neuroimage 24, 898-909.

Strange, B. A., and Dolan, R. J. (2004). Beta-adrenergic modulation of emotional memory-evoked human amygdala and hippocampal responses. Proc. Natl. Acad. Sci. U.S.A. 101, 11454-11458.

Swanson, C. J., and Schoepp, D. D. (2003). A role for noradrenergic transmission in the actions of phencyclidine and the antipsychotic and antistress effects of mGlu $2 / 3$ receptor agonists. Ann. N. Y. Acad. Sci. 1003, 309-317.

Tait, D. S., Brown, V. J., Farovik, A., Theobald, D. E., Dalley, J. W., and Robbins, T. W. (2007). Lesions of the dorsal noradrenergic bundle impair set-shifting in the rat. Eur. J. Neurosci. 25, 3719-3733.

Takahashi, K., Kayama, Y., Lin, J. S., and Sakai, K. (2010). Locus coeruleus neuronal activity during the sleepwaking cycle in mice. Neuroscience 169, 1115-1126.

Takeuchi, T., Miyasita, A., Inugami, M., and Yamamoto, Y. (2001). Intrinsic dreams are not produced without REM sleep mechanims: evidence through elicitation of sleep onset periods. J. Sleep Res. 10, 43-52.

Takeuchi, T., Ogilvie, R. D., Ferrelli, A. V., Murphy, T., Yamamoto, Y., and Inugami, M. (1999). Dreams are not produced without REM sleep mechanisms. Sleep Res. Online 2(Suppl. 1), 279.

Tokizane, T. (1965). "Sleep mechanism: hypothalamic control of cortical activity," in Aspects anatomofonctionnels de la physiologie $d u$ sommeil, ed. CNRS (Paris: CNRS), 151-185.

Tong, J., Hornykiewicz, O., and Kish, S. J. (2006). Identification of a noradrenaline-rich subdivision of the human nucleus accumbens. $J$. Neurochem. 96, 349-354.

Tracy, R. L., and Tracy, L. N. (1974). Reports of mental activity from sleep stages 2 and 4. Percept. Mot. Skills 38, 647-648.

Tran, L., and Keele, N. B. (2011). Pchlorophenylalanine increases glutamate receptor 1 transcription in rat amygdala. Neuroreport 22, 758-761.

Uhlaas, P. J., and Singer, W. (2010). Abnormal neural oscillations and synchrony in schizophrenia. Nat. Rev. Neurosci. 11, 100-113.

Verhelj, M. M., and Cools, A. R. (2009a). Accumbental noradrenaline that contributes to the alpha-adrenoceptor-mediated release of dopamine from reserpinesensitive storage vesicles in the nucleus accumbens is derived from alpha-methyl-para-tyrosinesenitive pools. J. Neural Transm. 116, 389-394.

Verhelj, M. M., and Cools, A. R. (2009b). Mesolimbic alpha-, but not beta-adrenoceptors control the accumbal release of dopamine that is derived from reserpine-sensitive storage vesicles. Neuroscience 162, 1163-1173.

Vertes, R. (2004). Memory consolidation in sleep; dream or reality. $\mathrm{Neu}$ ron 44, 135-144.

Vertes, R., and Siegel, J. (2005). Time for the sleep community to take a critical look at the purported role of sleep in memory processing. Sleep 28, 1228-1229.

Wallace, D. M., Magnuson, D. J., and Gray, T. C. (1992). Organization of amygdaloid projections to brainstemp dopaminergic, noradrenergic, and adrenergic cell groups in the rat. Brain Res. Bull. 28, 447-454.

Wang, Y., Liu, J., Gui, Z. H., Ali, U., Fan, L. L., Hou, C., Wang, T., Chen, T., and Li, Q. (2011). Alpha2-adrenoceptor regulates the spontaneous and the GABA/glutamate modulated firing activity of the rat medial prefrontal cortex pyramidal neurons. Neuroscience 182, 193-202.

Wang, Y., Zhang, G. J., Liu, J., Ali, U., Gui, Z. H., Hui, Y. P., Wang, T., Chen, L., and Li, G. (2010). Noradrenergic lesion of the locus coeruleus increases the firing activity of the medial prefrontal cortex pyramidal neurons and the role of alpha2-adrenoreceptors in normal and medial forebrain bundle lesioned rats. Brain Res. 1324, 64-74.

Warren, R. A., and Dykes, R. W (1996). Transient and long-lasting effects of iontophoretically administered norepinephrine on somatosensory cortical neurons in halothaneanesthetized cats. Can. J. Physiol. Pharmacol. 74, 38-57.

Waterhouse, B. D., Azizi, S. A., Burne, R. A., and Woodward, D. (1990). Modulation of rat cortical area 17 neuronal responses to moving visual stimuli during norepinephrine and serotonin microiontophoresis. Brain Res. 514, 276-292.

Waterhouse, B. D., Moises, H. C., and Woodward, D. J. (1998). Phasic activation of the locus coeruleus enhances responses of primary sensory cortical neurons to peripheral receptive field stimulation. Brain Res. 790, 33-44.

Weinberger, D. R., Berman, K. F., and Zec, R. F. (1986). Physiological dysfunction of dorsolateral prefrontal cortex in schizophrenia 1. Regional cerebral blood flow evidence. Arch. Gen. Psychiatry 43, 114-124.

Williams, H. L., Hammack, J. T., Daly, R. L., Dement, W. C., and Lubin, A. (1964). Responses to auditory stimulation, sleep loss and the EEG stages of sleep. Electroencephalogr Clin. Neurophysiol. 16, 269-279.

Williams, H. L., Tepas, D. I., and Morlock, J. H. C. (1962). Evoked responses to clicks and electroencephalographic stages of sleep in man. Science 138, 685-686.

Young, C. E., Arima, K., Hu, L., Beach, T. G., Falkai, P., and Honer, W. G. (1998). SNAP-25 deficit and hippocampal connectivity in schizophrenia. Cereb. Cortex 8, 261-268.

Zhang, J. X., Harper, R. M., and Frysinger, R. C. (1986). Respiratory modulation of neuronal discharge in the central nucleus of the amygdala during sleep and waking states. Exp. Neurol. 91, 193-207.

Conflict of Interest Statement: The author declares that the research was conducted in the absence of any commercial or financial relationships that could be construed as a potential conflict of interest.

Received: 13 September 2011; accepted: 23 November 2011; published online: 12 December 2011.

Citation: Gottesmann C (2011) The involvement of noradrenaline in rapid eye movement sleep mentation. Front. Neur. 2:81. doi: 10.3389/fneur.2011.00081 This article was submitted to Frontiers in Sleep and Chronobiology, a specialty of Frontiers in Neurology.

Copyright $\odot 2011$ Gottesmann. This is an open-access article distributed under the terms of the Creative Commons Attribution Non Commercial License, which permits non-commercial use, distribution, and reproduction in other forums, provided the original authors and source are credited. 